\title{
Estimation of Protein and Productive Efficiency Profile of Locally Produced Oyster Mushroom (Pleurotus Ostreatus) in Broiler
}

\section{Muhammad IIfan Ullah}

Bahauddin Zakariya University

\section{Muhammad Umar ljaz}

University of Agriculture Faisalabad

Ghulam Hussain

Government College University Faisalabad

Muhammad Naeem Faisal

University of Agriculture Faisalabad

Azhar Rasul

Government College University Faisalabad

Shazia Anwer Bukhari

Government College University Faisalabad

Imtiaz Mustafa

Government College University Faisalabad

Haseeb Anwar ( $\boldsymbol{\nabla}$ drhaseebanwar@gcuf.edu.pk)

Government College University

\section{Research article}

Keywords: Pleurotus ostreatus, Broiler, Oxidative Stress, Production Profile, Immunomodulator

Posted Date: October 5th, 2020

DOI: https://doi.org/10.21203/rs.3.rs-71550/v1

License: (1) (1) This work is licensed under a Creative Commons Attribution 4.0 International License. Read Full License 


\section{Abstract}

Background: Pleurotus ostreatus (Oyster) is a worldwide used mushroom, known to have a wide range of nutrients. Effects of the ethanolic and aqueous extracts of Oyster and its isolated proteins on the production profiles and bio health markers in broiler birds were evaluated in the present research.

Methods: Four hundred and twenty, day-old Ross-308 broiler birds were distributed into seven groups with sixty number of birds in each group $(\mathrm{N}=60)$. Each group was divided into three subgroups with twenty number of birds in each subgroup ( $\mathrm{N}=20)$. The first group was selected as control (CONT) with no treatment and other six groups were supplemented orally with the mushroom protein at a dose of 200 (Pr200) and 400mg/Kg BW (Pr400), an aqueous extract of mushroom at a dose of 200 (Aq200) and $400 \mathrm{mg} / \mathrm{Kg} \mathrm{BW}$ (Aq400) and ethanolic extract of mushroom at a dose of 200 (Eth200) and $400 \mathrm{mg} / \mathrm{Kg} \mathrm{BW}$ (Eth400) respectively. On day $28^{\text {th }}$ of the experiment, $1^{\text {st }}$ sub-group of each group was evaluated for cellmediated immunity by assessing the lymphoproliferative reaction to Phytohemagglutinin-P (PHA-P; Toe web assay) and the humoral immune reaction was evaluated in the $2^{\text {nd }}$ subgroup of each group by antibody reaction to sheep red blood cells (sRBCs; Hemagglutination assay). On day 42, serum was separated by slaughtering (decapitation) all the birds and evaluated for the oxidative stress, lipid profile, blood glucose level, and immune parameters. One-way analysis of variance (ANOVA), Tuckey range tests, and geometric mean titer (GMT) was used to statistically analyze the results.

Results: The Eth400 birds showed significantly $(P<0.05)$ higher cell-mediated immune response $(1.1 \pm 0.04$ $\mathrm{mm})$ and humoral immune response $(49.31 \pm 0.03 \mathrm{~mm})$ in comparison with the control group. Birds supplemented with mushroom extracts and protein revealed significantly greater growth performance, maximum in Eth400, in terms of feed conversion ratios (FCR; $1.44 \pm 0.002)$ when compared with the control group $(1.7 \pm 0.01)$.

Conclusion: Different parameters to evaluate oxidative stress showed that the mushroom extracts and its protein reduced the oxidative stress in the treated groups being maximum in Eth400. Conclusively, the oyster mushroom has health promoting effects in term of production profile, as immunomodulator and antioxidant in broiler poultry.

\section{Background}

Poultry diet with specific inclusion of mushroom is one of the substitutes attaining much importance among the poultry farmers and nutritionists, because many of the biologically active compounds like proteins, polysaccharides and polysaccharide-protein complexes have been separated from the mushrooms and analyzed for their antimicrobial, antiparasitic, immune enhancing and antiviral activities (1). Polysaccharides and many other bioactive compounds in the mushrooms have been evaluated and considered to have useful effects on growth performance and immune responses (2). One of the active compound, A xylose lectin which is isolated from Xylaria hypoxylon showed remarkable anti tumour activities and antimitogenic (3). Similarly, Zhang et al., 2009 separated lectin from the Pholiota adiposa 
through DEAE cellulose filtration method followed by carboxy methyl cellulose and a fast protein by using liquid chromatography gel filtration on the superdex 75 resulted in excellent antitumor effect against mammary hepatomas and tumor (4). Various studies have been performed in the past decade to isolate proteins responsible for the inactivation of ribosomes, from Flammulina velutipes, and Calvatia caelata Hypsizigus marmoreus and these proteins work by removing one or more than one of adenosine residue from rRNA. Various therapeutic effects have been observed by these proteins including antitumour, immunomodulatory and antifungal, activities (5). An antiviral substance laccase has been separated from Pleurotus ostreatus (6). In all the therapeutically active compounds isolated so far, protein related compounds like antifungal, immunomodulatory proteins, ribosomal inhibiting proteins, ribonulcleases, proteins for antimicrobial effect, laccases and lectins are of important concerns (7); (8). Proteins separated from the mushrooms might be a unique source of nutrition for the poultry industry of Pakistan.

On the basis of proved therapeutically effective mushrooms are the most important source of various thoroughly studied preparations. Along with the isolation of glycogen-like polysaccharides, (1-4)-, (1-6)a-D-glucans and antitumor polysaccharides, (1-3)-, heterogalactans, (1-6)- $\beta$-bonded heteroglucans, xyloglucans, heteromannans, and lentinan have also been identified in mushrooms (9). Lentinan stimulates many types of macrophage-dependent immune reactivity, T cell-, NK cell- and B cell. Mushrooms may also possess many therapeutically effective moieties i.e protocatechuic acid, gallic acid, naringenin, chlorogenic acid, biochanin-A and hesperidin (10); (11). Due to the presence of crude fiber which are indigestible, fraction amount of the carbohydrates or polysaccharides, low fat and sugars have an important function in the digestive system of broilers, thereby potentiating the growth rate of nonpathogenic bacteria i.e one of the specie Bifidobacterium (12). Polysaccharides from herbs and mushrooms have been utilized as immunomodulator or immune enhancers and resulted in antiparasitic, antiviral, antibacterial and anticarcinogenic bioactivities (13). Along with the polymers ( $\beta$-glucans) obtained from mushroom can enhance the response of immune cells in human and animals by binding to other receptors like Dectin-1 (14). One of the mushroom which is oyster mushrooms (Pleurotus ostreatus) found to possess immunomodulatory effects and having antioxidant potential (15) has also been proved to improve the intestinal health, immunity and growth in poultry (16); (17); (18). In an experiment on layer, Cho et al. (2010) (19) found that fermented spent mushroom compound may be utilized as an important resource in laying hen which fed at 5-15\% without negatively affecting the egg quality and their effective performance related to laying eggs.

Several studies demonstrated the isolated proteins as antitumor, antioxidative, and immunomodulatory response in various species (20). Supplementation of one of the most important components from the locally available mushroom (Pleurotus ostreatus) like FIPs (Fungal Immunomodulatory Proteins) added in the broiler feed can potentiate immunity and growth of broilers. This recent literature may be a food for thought for the farmers to utilize this natural protein which are the best source for the chickens in having biological effect of good immunomodulator which may be cost effective for the farmers by firstly enhancing the production profiles and secondly by decreasing the economy of medication. So, Current study is designed to separate the proteins from Pleurotus ostreatus and evaluation of these proteins and 
ethanolic and aqueous extracts of the oyster mushroom on immunity, oxidative stress and production profiles of broiler poultry.

\section{Methods}

\section{Procurement and processing of Pleurotus ostreatus}

Oyster mushroom used in the present study was procured from Department of Horticulture, University of Agriculture, Faisalabad, Pakistan. The mushroom specimen was identified by an expert botanist from Department of Botany, Government College University, Faisalabad. Six hundred grams of the fresh mushroom was used for proximate analysis. The remaining mushroom after washing with distilled water, was shade dried under sun light and grinded to form fine powder. After the qualitative and quantitative analysis of amino acids, the mushroom powder was used for the isolation of proteins and ethanolic and aqueous extracts preparation to be used in the experimental trial in broiler poultry feed.

\section{Proximate analysis}

Proximate analysis was done according to the procedure described by Agrahar-Murugkar and Subbulakshmi 2004 (21). Briefly, $5 \mathrm{~g}$ of the mushroom sample was placed in oven at $105^{\circ} \mathrm{C}$ for 5 hours, the loss of moister was calculated and expressed as percent moisture. Soxhlet extraction method was used for quantification of fat content using the solvent petroleum ether. Ash was estimated by incineration of known quantity of powdered mushroom sample at $550^{\circ} \mathrm{C}$ in electric furnace. Carbohydrates were quantified by using anthrone reagent (21).

\section{Aqueous and Ethanolic Extract Preparation}

The dried mushroom powder was subjected to ethanolic and aqueous extraction. The dried sample (500

g) was extracted with $2000 \mathrm{ml}$ solvent, distilled water and absolute (95\%) Ethanol at room temperature for $24 \mathrm{~h}$ and filtered through Whatman filter paper No. 4. Both the ethanolic and aqueous residues were re extracted twice and the filtrates were collected to evaporate almost to dryness in a rotary evaporator (Scilogex RE-100 pro; USA) at $40{ }^{\circ} \mathrm{C}$. The dried extracts were stored at $4{ }^{\circ} \mathrm{C}$ to be used for clinical trial (22).

\section{Amino acid analysis of Aqueous and Ethanolic Extracts}

Amino acids present in the mushroom extracts were quantified by using the Amino Acid Analyzer (TSM1 Technicon Instrument Basingstoke, UK). Norleucine was used as standard.

\section{Protein Isolation}

Proteins were isolated from the dried fruiting bodies of the mushroom Pleurotus ostreatus by following the previously described method (8). Briefly, $100 \mathrm{~g}$ of mushroom powder was dissolved in $0.15 \mathrm{M}$ sodium chloride at and soaked overnight at $4^{\circ} \mathrm{C}$. After centrifugation for $15 \mathrm{~min}$ at $8000 \mathrm{~g}, 1 \mathrm{M}$ ammonium sulfate was added to almost $80 \%$ saturation. After a second centrifugation, extra $\left.\mathrm{NH}_{4}\right)_{2} \mathrm{SO}_{4}$ was removed by 
dialyzing twice with PBS. The extracted proteins were finally purified by ion exchange chromatography by using DEAE-cellulose column which was equilibrated with PBS with N-acetyl, D-Galactosamine (12.5mM). The quantification of the extracted proteins was done by using Bradford's method (23) with bovine serum Albumin (BSA) as standard protein with six different concentrations $(0-30 \mu \mathrm{g} / \mathrm{ml})$.

\section{Clinical Trial}

Four hundred and twenty, day old broiler birds (Ross-308) were procured from a commercial hatchery, Faisalabad and reared at the Animals Experiment station, Department of Physiology, Government College University Faisalabad, Pakistan. Chicks were reared under standard management practices. All the chicks were kept on mash feed ration. The birds were randomly distributed into seven groups $(\mathrm{N}=60)$ with three replicates in each group with 20 number of birds in each replicate $(n=20)$ (table. 1). First group was selected as control and other six groups Pr200, Pr400, Aq200, Aq400, Eth200, and Eth400 were supplemented orally with Mushroom protein at dose of $200 \mathrm{mg} / \mathrm{kg} \mathrm{BW}, 400 \mathrm{mg} / \mathrm{Kg}$ BW, Aqueous extract of mushroom at dose of $200 \mathrm{mg} / \mathrm{Kg} \mathrm{BW}, 400 \mathrm{mg} / \mathrm{Kg}$ BW and ethanolic extract of mushroom at dose of $200 \mathrm{mg} / \mathrm{Kg} \mathrm{BW}, 400 \mathrm{mg} / \mathrm{Kg}$ BW respectively. The dose of different treatments was measured daily on penbased weight measurement to cope with the daily weight gain of the birds. A complete basal diet was formulated for each of the 3 stages of growth: starter, grower, and finisher (table 2). Water was provided ad libitum to all the birds in each of the 7 groups. Weight of birds in all groups along with food consumption were recorded at $3^{\text {rd }}, 5^{\text {th }}$ and $7^{\text {th }}$ week interval to assess the performance profile and FCR of the birds in all the groups.

On day $28^{\text {th }}$ of the experiment, $1^{\text {st }}$ replicate of each group was assessed for cell mediated immunity by assessing the lymphoproliferative reaction to Phytohemagglutinin-P (PHA-P; Toe web assay) (24) and humoral immune reaction was evaluated in the $2^{\text {nd }}$ replicate of each group by antibody reaction to sheep red blood cells (RBCs; Hemagglutination assay) (25); (26); (27).

\section{Sampling}

At the end of the experiment at day 42 a total of 6 birds from control group and each sub-group of all the treatment groups were slaughtered (decapitation) for blood collection. During the experiment, the blood was taken from jugular vein in EDTA tubes for hematology and clot activator tubes for serum separation. Serum was separated and stored at $-20^{\circ} \mathrm{C}$ for biochemical analysis related to oxidative stress, lipid profile and immune parameters.

\section{Toe web Assay}

At day $28^{\text {th }}$ of the experiment, $1^{\text {st }}$ replicate of each group was injected $0.1 \mathrm{ml}$ of PHA-P (Sigma ${ }^{\circledR}$, USA; $100 \mu \mathrm{g} / 100 \mu \mathrm{l})$ and PBS in the toe web between $3^{\text {rd }}$ and $4^{\text {th }}$ digit of right and left foot respectively. Thickness of toe web skin of injected feet of birds was measured before the injections and after the 24 , 48 and 72 hours of injections, using micrometer screw gauge. Final values of lymphoproliferative reaction to PHA-P was measured by means of following equation: 
Lymphoproliferative reaction $=($ PHA-P reaction, right foot $)-($ PBS reaction, left foot $)$.

\section{Hemagglutination assay}

Sheep RBCs were used as T-dependent antigen to evaluate the antibody reaction. Antibodies IgG (mercaptoethanol-resistant) and IgM (mercaptoethanol-sensitive) were estimated in the treatment groups compared with the control group (25). At day $28^{\text {th }}$ of the experiment, $2^{\text {nd }}$ replicate of each group was injected intramuscular with $5 \%$ suspension of sheep RBCs $(1 \mathrm{ml})$. At $7^{\text {th }}$ day of injection, a $2^{\text {nd }}$ dose of sheep RBCs was injected. Anti-sheep RBCs immunoglobulin titers were identified by hemagglutination assay in the serum of experimental birds (26); (27).

\section{Total Antioxidant Capacity, (TAC, mmol Trolox equiv. $^{L^{-1}}$ )}

Nisar et al. (28) described the method to evaluate the total antioxidant capacity (TAC) in the serum samples. Briefly it's a colorimetric assay based on bleaching of ortho dianisidine color in the assay reagent by the presence of antioxidants in the sample. Increased level of antioxidants in the sample leads to the increased bleaching and decreased absorbance which shows an inverse standard curve. Semi auto analyser Biolab ${ }^{\circledR} 320$ was used adjusted on bichromatic wavelength ( 660 and $870 \mathrm{~nm}$ ) by calibrating vitamin $C$ standards at concentrations of $1,3,5$, and $7 \mathrm{mmol} / \mathrm{L}$. The minimum measurable value of this assay was $0.18 \mathrm{mmol} \cdot \mathrm{L}^{-1}$ and the linearity was up to $7 \mathrm{mmol}$ vitamin $C$ equivalent $\cdot \mathrm{L}^{-1}$, with an intra assay coefficient of variance (CV) below $3 \%(29) ;(30)$.

\section{Total Oxidant Status (TOS; $\mu \mathrm{mol} \mathrm{H}_{2} \mathrm{O}_{2}$ equiv. $\mathrm{L}^{-1}$ )}

Methodology for measuring the serum TOS was adopted as described by Nisar et al. Calibration curve was prepared from different concentrations of hydrogen peroxide $\left(\mathrm{H}_{2} \mathrm{O}_{2}\right)$ and TOS was expressed as $\mu \mathrm{mol}$ of $\mathrm{H}_{2} \mathrm{O}_{2}$ equivalent/l. The precision value of the assay was up to $<3 \%$ and Intra assay coefficient of variance (CV) was kept under $10 \%$. The linearity of the assay was up to $200 \mu \mathrm{mol} \mathrm{H}_{2} \mathrm{O}_{2}$ equivalent /I (31); (30).

\section{Paraoxonase activity (U/L)}

The method described by Juretic (2006) was used for the estimation of paraoxonase activity in the serum samples. The activity of the enzyme paraoxonase was calculated by using the formula described in the reference methodology and expressed in Unit/min/I. Intra assay CV was below $10 \%$ and a reaction rate/hydrolysis rate of paraoxon was stable up to $5 \mathrm{~min}$. The minimum level of activity for this assay ranged from 80 to $100 \mathrm{U} / \mathrm{min} / \mathrm{I}$ (32); (30); (33).

\section{Arylesterase Activity (KU/L)}

The enzymatic activity of arylesterase was evaluated by following the procedure as previously adopted by Juretic, 2006. The enzymatic activity of the arylesterase was calculated by using the prescribed 
formula given in reference method. Intra assay CV was below $7 \%$ and initial rate of hydrolysis of paraoxon was stable up to 5 min.(32); (30); (33).

\section{Statistical Analysis}

One-way analysis of variance (ANOVA) and Tuckey range tests were adopted to analyze the statistical significance of results of weekly weight gain, Feed conversion ratio (FCR) and other biochemical analysis related to oxidative stress and lipid profile, using SPSS ${ }^{\circledR}, 23$ software. Data on antibody reaction to sheep RBCs was evaluated by geometric mean titer (GMT). Value of $p<0.05$ was considered statistically significant.

\section{Results}

\section{Proximate Analysis of oyster mushroom}

Proximate composition of the dried mushroom powder is given in the table 3 . The results are given in mean values of three replicates of the mushroom powder. Results show high carbohydrate $(48.36 \mathrm{~g} / 100 \mathrm{~g})$ and protein contents $(33.24 \mathrm{~g} / 100 \mathrm{~g})$ and low-fat content $(1.2 \mathrm{~g} / 100 \mathrm{~g})$. Moisture content is 3.84 and ash is $14.34 \mathrm{~g} / 100 \mathrm{~g}$ whereas the mushroom contains $405 \mathrm{kcal} / 100 \mathrm{~g}$ of energy.

\section{Amino acid composition of oyster mushroom}

Crude powder of the mushroom was evaluated for the presence or absence of different amino acids and the results are given in table 4. Ethanolic and aqueous extracts of the mushroom were evaluated the quantity of different amino acids and the results are given in the table 5 . Glycine $(210.53 \mathrm{mg} / \mathrm{g})$ was found maximum in aqueous extract whereas B-alanine was higher in aqueous extract $(31.56 \mathrm{mg} / \mathrm{g})$. Lowest concentration of Proline amino acid was seen in both the extracts.

\section{Protein quantification in isolated protein of Oyster mushroom}

The mean value of 3 replicates of protein samples was $27.42 \mu \mathrm{g} / \mathrm{ml}$.

\section{Production Profile}

Results of body weights and feed conversion ratio (FCR) of different groups of broiler birds at day 14, 28 and 42 are given as mean \pm SE is given in the figure 1, after applying one-way ANOVA. Our results showed that there is a significant increase in body weight of broiler chickens in all the treatment groups as compared with the control group, with the passage of experimental trial. Ethanolic extract of the mushroom at dose $400 \mathrm{mg} / \mathrm{kg}$ body weight has greater values of body weight as compared to other treatment groups and lower FCR values.

\section{Oxidative Stress}


Oxidative stress was measured in all the groups of broiler birds in terms of Total antioxidant capacity (TAC), Total oxidant status (TOS), Paraoxonase enzyme (PON) and Arylesterase enzyme (ARY) activity. The results, after analyzing with one-way ANOVA are shown in the figure 2. Oyster mushroom protein showed higher TAC levels in Pr400, Eth200 and Eth400 groups with significant difference as compared to control group. Mushroom proteins also increased antioxidant values in $\operatorname{Pr} 200$ ( $2.53 \mathrm{mmol} / \mathrm{l})$ as compared to control group. Whereas, TAC results of Aq200 (2.25 mmol/l) and Aq400 (2.2 mmol/l) are nonsignificantly different from the control group. Significantly lower values of TOS in the Eth 400 group shows that ethanolic extract of the oyster mushroom reduces oxidative stress at the dose of $400 \mathrm{mg} / \mathrm{kg}$ body weight. Moreover, the paraoxonase activity is also significantly higher in the same ethanolic extract treated group $\left(161.35 \mathrm{U} \mathrm{min}^{-1} \mathrm{ml}^{-1}\right)$.

\section{Hematology, Serum Lipid Profile and Serum glucose level}

Mean values of Serum total cholesterol, Triglycerides, High density lipoproteins (HDL) and Low-density lipoproteins (LDL) are presented in the figure 3 and results of serum glucose level are given in figure 4 and Hematology results are shown in figure 5. Results of hematology and all the lipid profile parameters and serum glucose levels are non-significant among all the groups.

\section{Cell Mediated Immune Response}

Lymphoproliferative reaction to PHA-P was calculated and the results are shown in figure 6 in terms of differences $(\mathrm{mm})$ in the thickness of toe web at 24,48 and 72 hours post administration to PHA-P (means \pm standard error). All the treatment groups showed significantly higher $(P<0.05)$ lymphoproliferative reaction when compared with control after 72 hours of PHA-P injection. Maximum response was observed in ethanolic extract treated groups and that is in a dose dependent manner.

\section{Humoral Immunity}

For the evaluation of humoral immune response, antibody reaction to sheep RBCs is in the form of total antibody, IgM and IgG titers were determined. Results were shown in the form of geomean titers (GMT). Increased titers are seen in the ethanolic extract of oyster mushroom treated groups in a dose dependent manner (figure 7).

\section{Discussion}

Therapeutic use of mushrooms have been reported since centuries to be used in the treatment of different diseases and various efforts have been made since the second half of the last century to separate different biologically active substances from the mushrooms which are responsible for various pharmacological effects (34). Various substances with their immunodecorated effects have been isolated from different types of mushrooms and also have their subsequent factors against several ailments like inflammation (35), (36), food allergy (37), (38), tuberculosis (39), rheumatoid arthritis (40), 
hyperglycemia (41), (42), asthma (43), (44) atopic dermatitis (45), AIDS (46), atherosclerosis (47), thrombosis (48), listeriosis (49), septic shock (50) and various kinds of tumors (51); (52); (53); (54); (55).

Considering such a broad spectrum of action, and based on the recent literature data, the use of mushrooms is justified in the feeding of farm animals, including poultry (56).

Boletus badius was evaluated for the presence of phenolic compounds (protocatechuic acid, $p$ hydroxybenzoic acid, $p$-coumaric acid and cinnamic acid). Elmastas et al. (2007) (15) in their study showed that the total antioxidant activity of the extracts obtained from dried fruiting bodies of $B$. badius at a concentration of $100 \mu \mathrm{g} / \mathrm{mL}$ was $99.2 \%$. Another edible mushroom, Fistulina hepatica which is a very rich source of phenolic compounds specially protocatechuic acid and $p$-hydroxybenzoic acid contents in this species have been studied for tits antioxidant properties (57). The total amount of phenolic compounds determined by Muszyńska et al. (2013) (58) ranged from $6.00 \mathrm{mg} / \mathrm{kg}$ in A. mellea to $48.25 \mathrm{mg} / \mathrm{kg}$ in Boletus badius.

Such kind of versatile effects of mushrooms against several disorders need detailed work and, in this context, the current study was done to find out antioxidant activities and immunomodulatory effects of separated protein, Ethanolic and Aquous extracts of a locally available mushroom Pleurotus ostreatus in broiler chicken. Results of proximate analysis are described in table 2, which shows high carbohydrates and protein contents and low fat contents which are similar to another study on the oyster mushroom (59). Another study of Tolera et al, (60) also showed high content of carbohydrates, proteins and fibres in the fresh oyster mushroom sample as compared to dried mushroom sample. Mushrooms have a variable amount of Moisture content depending upon the location, environmental factors, harvesting season, and preservation conditions (61). High contents of fiber represent the mushroom as an efficient source of dietary fibers which can help to reduce high cholesterol levels and to decrease the risk of tumors (62).

Amino acids are important with respect to involving biological activities relative to human body as they are well known for building blocks of the body. Amino acids also serve in repairing of tissues as well as building block of cells and in formation of antibodies to kill viruses and bacteria. They are also important part of the enzymes that produced in body endocrine system (63). Results of amino acid analysis of our mushroom samples given in table 5 shows the concentration of different evaluated amino acids that varied significantly $(p<0.05)$ in all respective different extracts of mushrooms. Total sixteen different types of amino acids were detected in both the ethanolic and aqueous extracts that includes essential and non-essential amino acids.

Glycine $(210.53 \pm 6.32 \mathrm{mg} / \mathrm{g})$ was found high in aqueous extract. In ethanolic extract maximum amount of amino acid was B-ala i.e. $(31.56 \pm 1.58 \mathrm{mg} / \mathrm{g})$. Proline amino acid was observed in minimum amount among all extracts as discussed by (64) (65). Their occurrence in low concentration is might be due to their non-essential nature. Among specimen lowest concentration of proline i.e. $(0.03 \pm 0.00 \mathrm{mg} / \mathrm{g})$ was detected in ethanolic extract. 
Mean values of body weights and feed conversion ratio of different groups of broiler birds at day 14, 28 and 42 are given in the table 5. Our results showed that there is a significant increase in weight of the broiler in all the treated groups when compared with control group. Ethanolic extract of the mushroom at dose $400 \mathrm{mg} / \mathrm{kg}$ body weight has greater values of body weight as compared to other treatment groups and lower FCR values. In a previous study an extract of a common edible mushroom. Lentinus edodes, had a similar effect on the body weight (66). The significant increase in body weight and a lower ratio of FCR in the oyster mushroom protein and extracts treated groups may be due to its high nutrition value (67) which makes it the most widely cultivated mushroom in the world (68).

The results of oxidative stress in all the groups are given in the Fig. 2. Oyster mushroom protein at dose rate of $400 \mathrm{mg} / \mathrm{kg}$ of the body weight and its ethanolic extract at both lower (200 mg/kg body weight) and higher doses (400 mg/kg body weight) produced highest antioxidant levels with significant difference as compared with the control group. Mushroom proteins at lower dose (200 mg/kg body weight) also increased antioxidant values as compared with the control group. Values of TOS significantly lower level in the Eth400 group shows that ethanolic extract of the oyster mushroom reduces oxidative stress at the dose rate of $400 \mathrm{mg} / \mathrm{kg}$ of the weight of body. Moreover, in the group treated with ethanolic extract showed significantly higher level of the paraoxonase activity. In ethanolic extract treated group, higher antioxidant levels and lower TOS values may be due to the higher phenolic contents in the ethanolic extract because phenolics are directly involved in the antioxidant activity (69). Khatun et al. 2015 (68) reported the antioxidant activities of some pleurotus species mushrooms. They reported that pleurotus species are the best mushrooms in reducing the oxidative stress due to their higher phenolic and protein contents.

Results of all the lipid profile parameters and serum glucose levels, presented in Fig. 4 and Fig. 5 respectively, are non-significant among all the groups. A very limited data is available to study the effects of the mushroom on the lipid profile of the broiler birds with normal serum levels of glucose and lipid profile parameters. Although, various mushrooms including oyster mushroom have been studied by many researchers for their good anti hyper cholesterolemic and hypoglycemic effects in hypercholesterolemic or hyperglycemic animal models (70) (71). But in the present study the broiler birds are not induced any condition with associated abnormal levels of lipid profile so we could not see any significant difference in the serum glucose level and serum levels of lipid profile parameters among the control and treated birds.

Lymphoproliferative reaction to PHA-P was observed to elaborate the cell mediated immune response, and their results were shown in terms of variation $(\mathrm{mm})$ in the amplitude of swelling in toe web at 24,48 and 72 hours after giving PHA-P (means \pm standard error). Lymphoproliferative response was significantly greater $(P<0.05)$ in the treatment groups when compared with control. In ethanolic treated group, maximum response was found in a dose dependent manner (Fig. 6).

Immune system and oxidant status play an important role in body homeostasis and wellbeing. Any interruption in oxidative balance or in immune system may lead to different diseases. Precautions and preventions may significantly improve health status and protect from developing the several diseases. 
Supplementation of different types of immune boosters is generally recommended to prevent infectious diseases. The present study also evaluated the immune response of Oyster mushroom which shows that the mean value of cell mediated immune response was higher in the Eth400 group compared to the control groups. A study on partially purified polysaccharides from four medicinal mushroom species, has shown that the polysaccharides in the mushroom's extracts express an immunostimulating effect (72). In another study, the researchers purified the $(1 \rightarrow 6)-\beta$-d-glucans from an edible Agaricus bisporus and evaluated its effect on innate immunity. They concluded that $(1 \rightarrow 6)-\beta$-d-glucans present in Agaricus bisporus has the immunostimulatory effect (73). The mode of immunomodulatory effect of mushroom can be attributed to its stimulatory effect on different immune component cells, like, B lymphocytes, $T$ lymphocytes and granulocytes, macrophages and natural killer cells, monocytes and dendritic cells (74). These mushroom contents also have inhibitory effect on the pro-inflammatory genes expression and ultimately reduce the inflammation by inhibiting IL-1 and COX-2 proteins (73).

Previous studies showed significant increase in T cell proliferation (18\%) as reported by Liu et al., (1999) (75) in Marek's disease affected chickens and found with a significantly improved production of lymphocyte IL-2 (37-52\%). Another study in which polysaccharides present in Tremella fuciformis mushroom significantly improves the lymphocyte production and in cholera vaccine these polysaccharides were being used as adjuvants (76); (77); (78); (79). Present study has consistent results to a previous research in which greater humoral reaction was seen after supplementation of a mushroom Fomitella foraxina (80). Similarly, one more study was done on Tremella fuciformis and Lentinus edodes supplementation in broiler birds resulted in significant production of antibodies in the sera, identified after binding with the antigens, secreted from Eimeria tenella infection (81). Girard et al., (1997) also stated notable synthesis of particular antibodies including IgA, IgM and IgG in the intestinal mucosa of birds infected with Eimeria (82). Various factors are involved in the cells to produce different types of cytokines when some particular mushroom is supplemented as a part of diet to an animal. These differences in immune responses in the cells may be due to the presence of different physicochemical properties of mushrooms, such as, purity of polysaccharides and methods of preparation of the extracts (83); (84); (85).

\section{Conclusion}

The oyster mushroom showed good physiochemical properties in terms of its proximate composition and presence of a good amount of all the essential and non-essential amino acids. This shows the nutritious value of the mushroom along with its health promoting effects. The broiler birds when treated with isolated protein of the mushroom and its aqueous and ethanolic extract in two different doses, the treated birds showed significantly higher cell mediated immune response in terms of lymphoproliferative response to PHA-P $(P<0.05)$ as compared to control group being maximum in the ethanolic extract treated group. Humoral immune response in terms of antibody (total immunoglobulins $\lg , \lg \mathrm{M}$, $\lg \mathrm{G}$ ) titers to sheep RBCs was observed significantly $(P<0.05)$ higher in treatment groups as compared to control. The highest antibody titers were seen in ethanolic extract treated group. Birds supplemented with mushroom extracts and protein showed significantly higher growth performance in terms of weight gain 
and feed conversion ratios (FCR) in comparison to the control. Different parameters to evaluate oxidative stress also showed that the mushroom extracts and its protein possess antioxidant properties, hence can be used to reduce the oxidative stress in broiler chicken. The results of Hematology, Lipid profile and blood glucose level showed no significant changes in the treated groups from the control group, but the result of these parameters were in normal physiological values which can be concluded as the mushroom has no adverse effects on these parameters. So, the mushroom has health promoting effects in term of immunomodulator and antioxidant with a considerable amount of essential and non-essential amino acids.

\section{Abbreviations}

CONT

control; PHA-P:(Phytohemagglutinin-P; sRBCs:sheep red blood cells; ANOVA:analysis of variance; GMT:geometric mean titer; FCR:feed conversion ratios, TAC:Total antioxidant capacity; TOS:Total oxidant status.

\section{Declarations}

\section{Availability of data and materials}

The datasets used and/or analyzed during the current study are available from the corresponding author on reasonable request.

\section{Ethics approval and consent to participate}

The study has been approved by the Directorate of Advance studies, Government College University, Faisalabad, Pakistan.

\section{Consent for publication}

Not applicable.

\section{Competing interests}

All the authors declare that they have no conflict of interest.

\section{Funding}

The funding for the current experiment was provided by Pakistan Agricultural Research Council under Agricultural linkages program (ALP; AS014). 


\section{Authors' contributors}

HA and MIU conceptualized the study, IM, IM and HA performed the clinical trial and lab analysis. GH and AR helped IM in the mushroom extraction and analysis. IM and HA participated in technical writing of the manuscript. HA, SAB and MUI conducted a critical review of the manuscript. All authors read and approved the final manuscript.

\section{Acknowledgements}

Not Applicable

\section{References}

1. Xu X, Yan H, Chen J, Zhang X. Bioactive proteins from mushrooms. Biotechnol. Adv. 2011;29(6):66774.

2. Wasser SP. Medicinal mushroom science: history, current status, future trends, and unsolved problems. Int. J. Med. Mushrooms. 2010;12(1).

3. Liu Q, Wang H, Ng T. First report of a xylose-specific lectin with potent hemagglutinating, antiproliferative and anti-mitogenic activities from a wild ascomycete mushroom. Biochim. Biophys. Acta. 2006;1760(12):1914-9.

4. Zhang $\mathrm{G}$, Sun J, Wang $\mathrm{H}, \mathrm{Ng}$ T. A novel lectin with antiproliferative activity from the medicinal mushroom Pholiota adiposa. ACTA BIOCHIM POL. 2009;56(3).

5. Patel S, Goyal A. Recent developments in mushrooms as anti-cancer therapeutics: a review. 3 Biotech. 2012;2(1):1-15.

6. M EL-Fakharany E, M Haroun B, Ng T, M Redwan E-R. Oyster mushroom laccase inhibits hepatitis C virus entry into peripheral blood cells and hepatoma cells. PROTEIN PEPTIDE LETT. 2010;17(8):10319.

7. Li Y, Zhang G, Ng TB, Wang H. A novel lectin with antiproliferative and HIV-1 reverse transcriptase inhibitory activities from dried fruiting bodies of the monkey head mushroom Hericium erinaceum. Biomed Res. Int.. 2010;2010.

8. Zhang G, Sun J, Wang H, Ng T. First isolation and characterization of a novel lectin with potent antitumor activity from a Russula mushroom. Phytomedicine. 2010;17(10):775-81.

9. Hobbs C. Medicinal value of Lentinus edodes (Berk.) Sing.(Agaricomycetideae). A literature review. Int. J. Med. Mushrooms. 2000;2(4).

10. Alam N, Amin R, Khan A, Ara I, Shim MJ, Lee MW, et al. Nutritional analysis of cultivated mushrooms in Bangladesh-Pleurotus ostreatus, Pleurotus sajor-caju, Pleurotus florida and Calocybe indica. Mycobiology. 2008;36(4):228-32. 
11. Alam N, Yoon KN, Lee KR, Shin PG, Cheong JC, Yoo YB, et al. Antioxidant activities and tyrosinase inhibitory effects of different extracts from Pleurotus ostreatus fruiting bodies. Mycobiology. 2010;38(4):295-301.

12. Sundu B, Kumar A, Dingle J. Palm kernel meal in broiler diets: effect on chicken performance and health. WORLD POULTRY SCI J. 2006;62(2):316-25.

13. Guo F, Williams B, Kwakkel R, Li H, Li X, Luo J, et al. Effects of mushroom and herb polysaccharides, as alternatives for an antibiotic, on the cecal microbial ecosystem in broiler chickens. Poult. Sci. J. 2004;83(2):175-82.

14. Rowan NJ, Smith JE, Sullivan R. Immunomodulatory activities of mushroom glucans and polysaccharide-protein complexes in animals and humans (a review). Int. J. Med. Mushrooms. 2003;5(2).

15. Elmastas M, Isildak O, Turkekul I, Temur N. Determination of antioxidant activity and antioxidant compounds in wild edible mushrooms. J Food Compost Anal. 2007;20(3-4):337-45.

16. Daneshmand A, Sadeghi G, Karimi A. The effects of a combination of garlic, oyster mushroom and propolis extract in comparison to antibiotic on growth performance, some blood parameters and nutrients digestibility of male broilers. BRAZ J POULTRY SCI. 2012;14(2):141-7.

17. Giannenas I, Pappas I, Mavridis S, Kontopidis G, Skoufos J, Kyriazakis I. Performance and antioxidant status of broiler chickens supplemented with dried mushrooms (Agaricus bisporus) in their diet. Poult. Sci. J. 2010;89(2):303-11.

18. Guo F, Savelkoul H, Kwakkel R, Williams B, Verstegen M. Immunoactive, medicinal properties of mushroom and herb polysaccharides and their potential use in chicken diets. WORLD POULTRY SCI J. 2003;59(4):427-40.

19. Cho YJ, Choi EJ, Shin PG, Yoo YB, Cho YU, Kim HC, et al. Effect of spent mushroom (Pleurotus

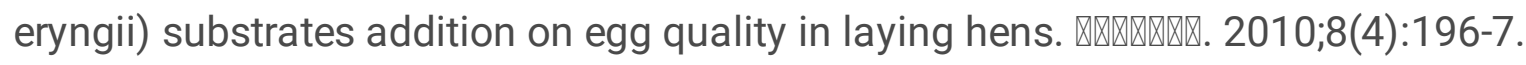

20. Khan SH, Mukhtar N, Iqbal J. Role of Mushroom as Dietary Supplement on Performance of Poultry. J. Diet. Suppl. 2019;16(5):611-24.

21. Agrahar-Murugkar D, Subbulakshmi G. Nutritional value of edible wild mushrooms collected from the Khasi hills of Meghalaya. Food Chem. 2005;89(4):599-603.

22. Bibi J, Mahnoor BN. In-Vitro Efficacy of Crude Extract of Zizipus Jujuba against Selected Bacterial Strains. Int J Sci Res Pub.514.

23. Bradford MM. A rapid and sensitive method for the quantitation of microgram quantities of protein utilizing the principle of protein-dye binding. Anal. Biochem. 1976;72(1-2):248-54.

24. Corrier DE. Comparison of phytohemagglutinin-induced cutaneous hypersensitivity reactions in the interdigital skin of broiler and layer chicks. Avian dis. 1990:369-73.

25. Qureshi M, Havenstein G. A comparison of the immune performance of a 1991 commercial broiler with a 1957 randombred strain when fed "typical" 1957 and 1991 broiler diets. Pout. sci. j. 1994;73(12):1805-12. 
26. YAMAMOTO Y, GLICK B. A comparison of the immune response between two lines of chickens selected for differences in the weight of the bursa of Fabricius. Pout. sci. j. 1982;61(10):2129-32.

27. Brugh JM. A simple method for recording and analyzing serological data. Avian Dis. 1978;22(2):3625.

28. Nisar J, Mustafa I, Anwar H, Sohail MU, Hussain G, Ullah MI, et al. Shiitake Culinary-Medicinal Mushroom, Lentinus edodes (Agaricomycetes): a Species with Antioxidant, Immunomodulatory, and Hepatoprotective Activities in Hypercholesterolemic Rats. Int. j. med. mushrooms. 2017.

29. Erel O. A novel automated method to measure total antioxidant response against potent free radical reactions. Clin. biochem. 2004;37(2):112-9.

30. Nisar J, Mustafa I, Anwar H, Sohail MU, Hussain G, Ullah MI, et al. Shiitake culinary-medicinal mushroom, Lentinus edodes (Agaricomycetes): a species with antioxidant, immunomodulatory, and hepatoprotective activities in hypercholesterolemic rats. Int. j. med. mushrooms. 2017;19(11).

31. Erel O. A new automated colorimetric method for measuring total oxidant status. Clin. biochem. 2005;38(12):1103-11.

32. Anwar H, Rahman Z, Javed I, Muhammad F. Effect of protein, probiotic, and symbiotic supplementation on serum biological health markers of molted layers. Poult. sci. j. 2012;91(10):2606-13.

33. Juretić D, Motejlkova A, KUNOVIC B, REKIC B, FLEGAR-MESTRIC Z, VUJIC L, et al. Paraoxonase/arylesterase in serum of patients with type II diabetes mellitus. Acta pharmaceutica. 2006;56(1):59-68.

34. Wasser S. Medicinal mushrooms as a source of antitumor and immunomodulating polysaccharides. Appl Microbiol Biotechnol. 2002;60(3):258-74.

35. Jose N, Ajith T, Janardhanan K. Methanol extract of the oyster mushroom, Pleurotus florida, inhibits inflammation and platelet aggregation. Phytother R. 2004;18(1):43-6.

36. Kim S-H, Song Y-S, Kim S-K, Kim B-C, Lim C-J, Park E-H. Anti-inflammatory and related pharmacological activities of the n-BuOH subfraction of mushroom Phellinus linteus. J. Ethnopharmacol. 2004;93(1):141-6.

37. Li X-M, Zhang T-F, Huang C-K, Srivastava K, Teper AA, Zhang L, et al. Food Allergy Herbal Formula-1 (FAHF-1) blocks peanut-induced anaphylaxis in a murine model. J. Allergy Clin. Immunol.. 2001;108(4):639-46.

38. Hsieh KY, Hsu Cl, Lin JY, Tsai CC, Lin RH. Oral administration of an edible-mushroom-derived protein inhibits the development of food-allergic reactions in mice. Clin Exp Allergy. 2003;33(11):1595-602.

39. Markova N, Kussovski V, Drandarska I, Nikolaeva S, Georgieva N, Radoucheva T. Protective activity of Lentinan in experimental tuberculosis. Int. Immunopharmacol. 2003;3(10-11):1557-62.

40. Kim G-Y, Kim S-H, Hwang S-Y, Kim H-Y, Park Y-M, Park S-K, et al. Oral administration of proteoglycan isolated from Phellinus linteus in the prevention and treatment of collagen-induced arthritis in mice. Biol Pharm Bull. 2003;26(6):823-31. 
41. Gray A, Flatt P. Insulin-releasing and insulin-like activity of Agaricus campestris (mushroom). J. Endocrinol. 1998;157(2):259-66.

42. Liu Y-T, Sun J, Luo Z-Y, Rao S-Q, Su Y-J, Xu R-R, et al. Chemical composition of five wild edible mushrooms collected from Southwest China and their antihyperglycemic and antioxidant activity. Food Chem. Toxicol. 2012;50(5):1238-44.

43. Li X-M, Huang C-K, Zhang T-F, Teper AA, Srivastava K, Schofield BH, et al. The Chinese herbal medicine formula MSSM-002 suppresses allergic airway hyperreactivity and modulates TH1/TH2 responses in a murine model of allergic asthma. J. Allergy Clin. Immunol. 2000;106(4):660-8.

44. Liu Y-H, Tsai C-F, Kao M-C, Lai Y-L, Tsai J-J. Effectiveness of Dp2 nasal therapy for Dp2-induced airway inflammation in mice: using oral Ganoderma lucidum as an immunomodulator. J Microbiol Immunol Infect. 2003;36(4):236-42.

45. Kuo Y-C, Huang Y-L, Chen C-C, Lin Y-S, Chuang K-A, Tsai W-J. Cell cycle progression and cytokine gene expression of human peripheral blood mononuclear cells modulated by Agaricus blazei. J Lab Clin Med. 2002;140(3):176-87.

46. Nanba H, Kodama N, Schar D, Turner D. Effects of maitake (Grifola frondosa) glucan in HIV-infected patients. Mycoscience. 2000;41(4):293-5.

47. Bobek P, Galbavý Š. Hypocholesterolemic and antiatherogenic effect of oyster mushroom (Pleurotus ostreatus) in rabbits. Food/Nahrung. 1999;43(5):339-42.

48. Yoon S-J, Yu M-A, Pyun Y-R, Hwang J-K, Chu D-C, Juneja LR, et al. The nontoxic mushroom Auricularia auricula contains a polysaccharide with anticoagulant activity mediated by antithrombin. Thromb. Res. 2003;112(3):151-8.

49. Kodama N, Yamada M, Nanba H. Addition of Maitake D-fraction reduces the effective dosage of vancomycin for the treatment of Listeria-infected mice. J Pharmacol Sci. 2001;87(4):327-32.

50. Kim G-Y, Roh S-I, Park S-K, Ahn S-C, Oh Y-H, Lee J-D, et al. Alleviation of experimental septic shock in mice by acidic polysaccharide isolated from the medicinal mushroom Phellinus linteus. Biol Pharm Bull. 2003;26(10):1418-23.

51. Chen Y-J, Shiao M-S, Lee S-S, Wang S-Y. Effect of Cordyceps sinensis on the proliferation and differentiation of human leukemic U937 cells. Life sci. 1997;60(25):2349-59.

52. Yoo H-S, Shin J-w, Cho J-H, Son C-G, Lee Y-W, Park S-y, et al. Effects of Cordyceps militaris extract on angiogenesis and tumor growth. Acta Pharmacol. Sin. 2004;25(5):657-65.

53. Lee H, Kim YJ, Kim HW, Lee DH, Sung M-K, Park T. Induction of apoptosis by Cordyceps militaris through activation of caspase-3 in leukemia HL-60 cells. Biol Pharm Bull. 2006;29(4):670-4.

54. Yang C-M, Zhou Y-J, Wang R-J, Hu M-L. Anti-angiogenic effects and mechanisms of polysaccharides from Antrodia cinnamomea with different molecular weights. J. Ethnopharmacol. 2009;123(3):40712.

55. Antonyuk V, Klyuchivska OY, Stoika R. Cytotoxic proteins of Amanita virosa Secr. mushroom: purification, characteristics and action towards mammalian cells. Toxicon. 2010;55(7):1297-305. 
56. Bederska-Łojewska D, Świątkiewicz S, Muszyńska B. The use of Basidiomycota mushrooms in poultry nutrition-A review. Anim. Feed Sci. Technol. 2017;230:59-69.

57. Vaz JA, Barros L, Martins A, Morais JS, Vasconcelos MH, Ferreira IC. Phenolic profile of seventeen Portuguese wild mushrooms. LWT-FOOD SCI TECHNOL. 2011;44(1):343-6.

58. Muszyńska B, Sułkowska-Ziaja K, Ekiert H. Phenolic acids in selected edible basidiomycota species: Armillaria mellea, Boletus badius, Boletus edulis, Cantharellus cibarius, Lactarius deliciosus and Pleurotus ostreatus. Acta Sci Pol Hortorum Cultus. 2013;12:107-16.

59. Sunday EA, Israel AU, Magu TO. Proximate analysis and mineral element composition of false yam (Icacina trichantha) tuber and oyster mushroom (Pleurotus ostreatus). Int. J. Chem. 2016;1(1).

60. Tolera KD, Abera S. Nutritional quality of Oyster Mushroom (Pleurotus Ostreatus) as affected by osmotic pretreatments and drying methods. FOOD SCI NUTR. 2017;5(5):989-96.

61. Crisan E, Sands A. Nutritional value: Academic Press, New York; 1978.

62. Okoro I, Achuba F. Proximate and mineral analysis of some wild edible mushrooms. Afr. J. Biotechnol. 2012;11(30):7720-4.

63. Kumar V, Abbas AK, Aster JC. Robbins basic pathology e-book: Elsevier Health Sciences; 2017.

64. Panthong S, Boonsathorn N, Chuchawankul S. Antioxidant activity, anti-proliferative activity, and amino acid profiles of ethanolic extracts of edible mushrooms. GMR (GENET MOL RES). 2016;15(4).

65. Asakawa Y. Fortschritte der Chemie organischer Naturstoffe/Progress in the Chemistry of Organic Natural Products: Springer Science \& Business Media; 2012.

66. Willis WL, Goktepe I, Isikhuemhen OS, Reed M, King K, Murray C. The effect of mushroom and pokeweed extract on Salmonella, egg production, and weight loss in molting hens. Poult. Sci. J. 2008;87(12):2451-7.

67. Barros L, Baptista P, Correia DM, Casal S, Oliveira B, Ferreira IC. Fatty acid and sugar compositions, and nutritional value of five wild edible mushrooms from Northeast Portugal. Food Chem. 2007;105(1):140-5.

68. Khatun S, Islam A, Cakilcioglu U, Guler P, Chatterjee NC. Nutritional qualities and antioxidant activity of three edible oyster mushrooms (Pleurotus spp.). NJAS-WAGEN J LIFE SC. 2015;72:1-5.

69. Orhan I, Üstün O. Determination of total phenol content, antioxidant activity and acetylcholinesterase inhibition in selected mushrooms from Turkey. J Food Compost Anal. 2011;24(3):386-90.

70. Alam N, Amin R, Khan A, Ara I, Shim MJ, Lee MW, et al. Comparative effects of oyster mushrooms on lipid profile, liver and kidney function in hypercholesterolemic rats. Mycobiology. 2009;37(1):37-42.

71. Agrawal R, Chopra A, Lavekar G, Padhi M, Srikanth N, Ota S, et al. Effect of oyster mushroom on glycemia, lipid profile and quality of life in type 2 diabetic patients. Aust. J. Medical Herbal. 2010;22(2):50.

72. Kozarski M, Klaus A, Niksic M, Jakovljevic D, Helsper JP, Van Griensven LJ. Antioxidative and immunomodulating activities of polysaccharide extracts of the medicinal mushrooms Agaricus 
bisporus, Agaricus brasiliensis, Ganoderma lucidum and Phellinus linteus. Food Chem. 2011;129(4):1667-75.

73. Smiderle FR, Alquini G, Tadra-Sfeir MZ, lacomini M, Wichers HJ, Van Griensven LJ. Agaricus bisporus and Agaricus brasiliensis $(1 \rightarrow 6)$ - $\beta$-d-glucans show immunostimulatory activity on human THP-1 derived macrophages. Carbohydr Polym. 2013;94(1):91-9.

74. Meng X, Liang H, Luo L. Antitumor polysaccharides from mushrooms: a review on the structural characteristics, antitumor mechanisms and immunomodulating activities. Carbohydr res. 2016;424:30-41.

75. Liu F, Ooi V, Fung M. Analysis of immunomodulating cytokine mRNAs in the mouse induced by mushroom polysaccharides. Life sci. 1999;64(12):1005-11.

76. Xia E, Cheng Q. Isolation, analysis and bioactivities of Tremella fuciformis fruit body polysaccharides. Acta Mycol. Sin. 1988;7(3):166-74.

77. Liang J, Hu T, Fan B. Experiment of 8301 polysaccharide including IFN production in rats. J Trad Chin Vet Med. 1995;4:12-3.

78. Hu T, Fan B, Huang Q. Effect of 8301 polysaccharides on spleen IL-2 production in rats. Chin J Vet Sci Technol. 1995;25:28.

79. Wang L, Liang Z, Feng W. Immunodulation of Astragalus membranacea Radix and Acanthopanax gracilistylus. J Chin Exp Clin Immunol. 1997;9:61-6.

80. Dalloul RA, Lillehoj HS. Recent advances in immunomodulation and vaccination strategies against coccidiosis. Avian dis. 2005;49(1):1-8.

81. Guo F, Kwakkel R, Williams B, Parmentier H, Li W, Yang Z, et al. Effects of mushroom and herb polysaccharides on cellular and humoral immune responses of Eimeria tenella-infected chickens. Poult Sci j. 2004;83(7):1124-32.

82. Girard F, Fort G, Yvore P, Quere P. Kinetics of specific immunoglobulin A, M and G production in the duodenal and caecal mucosa of chickens infected with Eimeria acervulina or Eimeria tenella. Int $\mathrm{J}$ Parasitol. 1997;27(7):803-9.

83. Fang B, Yuan Y, Liang J. Study of mechanism of enhanced avian cholera vaccine by 8301 polysaccharide. J Tradit Chin Vet Med. 1993;1:5-10.

84. Liang $\mathrm{H}$. Mechanism of the cellular immune function suppression and study on immune regulation by herbs in injured rats. J Third Mil Med Univ. 1996;18:352.

85. Wu Y, Wang F. Research status on herbs' twoway immune regulating functions. J Tradit Chin Vet Med. 1999;4:19-22.

\section{Tables}

Table: 1. Grouping of the broiler birds 


\begin{tabular}{|c|c|c|c|}
\hline $\begin{array}{l}\text { Groups } \\
N=60\end{array}$ & & $\begin{array}{l}\text { Replicates } \\
\mathrm{N}=20\end{array}$ & Treatment \\
\hline $\begin{array}{l}\text { Group } \\
1\end{array}$ & Control & $\begin{array}{l}\text { CONT-1 } \\
\text { CONT-2 } \\
\text { CONT-3 }\end{array}$ & No treatment \\
\hline $\begin{array}{l}\text { Group } \\
2\end{array}$ & $\begin{array}{l}\text { Treatment } \\
\text { group } 1\end{array}$ & $\begin{array}{l}\text { Pr200-1 } \\
\text { Pr200-2 } \\
\text { Pr200-3 }\end{array}$ & Mushroom Protein at dose $200 \mathrm{mg} / \mathrm{kg}$ body weight \\
\hline $\begin{array}{l}\text { Group } \\
3\end{array}$ & $\begin{array}{l}\text { Treatment } \\
\text { group } 2\end{array}$ & $\begin{array}{l}\text { Pr400-1 } \\
\text { Pr400-2 } \\
\text { Pr400-3 }\end{array}$ & Mushroom Protein at dose $400 \mathrm{mg} / \mathrm{kg}$ body weight \\
\hline $\begin{array}{l}\text { Group } \\
4\end{array}$ & $\begin{array}{l}\text { Treatment } \\
\text { group } 3\end{array}$ & $\begin{array}{l}\text { Aq200-1 } \\
\text { Aq200-2 } \\
\text { Aq200-3 }\end{array}$ & $\begin{array}{l}\text { Aquous extract of the mushroom at dose } 200 \mathrm{mg} / \mathrm{kg} \\
\text { body weight }\end{array}$ \\
\hline $\begin{array}{l}\text { Group } \\
5\end{array}$ & $\begin{array}{l}\text { Treatment } \\
\text { group } 4\end{array}$ & $\begin{array}{l}\text { Aq400-1 } \\
\text { Aq400-2 } \\
\text { Aq400-3 }\end{array}$ & $\begin{array}{l}\text { Aquous extract of the mushroom at dose } 400 \mathrm{mg} / \mathrm{kg} \\
\text { body weight }\end{array}$ \\
\hline $\begin{array}{l}\text { Group } \\
6\end{array}$ & $\begin{array}{l}\text { Treatment } \\
\text { group } 5\end{array}$ & $\begin{array}{l}\text { Eth200-1 } \\
\text { Eth200-2 } \\
\text { Eth200-3 }\end{array}$ & $\begin{array}{l}\text { Ethanolic extract of the mushroom at dose } 200 \mathrm{mg} / \mathrm{kg} \\
\text { body weight }\end{array}$ \\
\hline $\begin{array}{l}\text { Group } \\
7\end{array}$ & $\begin{array}{l}\text { Treatment } \\
\text { group } 6\end{array}$ & $\begin{array}{l}\text { Eth400-1 } \\
\text { Eth400-2 } \\
\text { Eth400-3 }\end{array}$ & $\begin{array}{l}\text { Ethanolic extract of the mushroom at dose } 400 \mathrm{mg} / \mathrm{kg} \\
\text { body weight }\end{array}$ \\
\hline
\end{tabular}

\section{Table 2: Ingredients and composition of basal feed ration $(\mathrm{g} / 100 \mathrm{~g})$}

aPremix / kg feed: Cholecalciferol 2200 U; Riboflavin 5.5 mg; Vitamin A 8300 U; D-calcium pantothenic acid $15 \mathrm{mg}$; Niacin 36 mg; Choline 500 mg; Folic acid 0.5 mg; Vitamin B1 1 mg; Pyridoxine 2.2 mg; Biotin 0.05 mg; Vitamin K 2 mg; Vitamin E 8 U; Vitamin B12 0.02 mg; Manganese 80 mg; Zinc 60 mg; Iron 60 mg; Copper $5 \mathrm{mg}$; Cobalt $0.2 \mathrm{mg}$; lodine $1 \mathrm{mg}$; Selenium $0.15 \mathrm{mg}$ 


\begin{tabular}{|c|c|c|c|c|}
\hline & Item & $\begin{array}{l}\text { Starter diet (1 to } \\
14 \mathrm{~d} \text { ) }\end{array}$ & $\begin{array}{l}\text { Grower diet ( } 15 \text { to } \\
28 \mathrm{~d} \text { ) }\end{array}$ & $\begin{array}{l}\text { Finisher diet ( } 29 \text { to } \\
42 \text { d) }\end{array}$ \\
\hline 1. & Corn grain & 515.6 & 532.2 & 561.5 \\
\hline 2. & Canola meal & 350.0 & 350.0 & 350.0 \\
\hline 3. & Canola oil & 35.0 & 33.0 & 33.0 \\
\hline 4. & Fish meal & 35.0 & 25.0 & 15.0 \\
\hline 5. & Corn gluten meal & 25.0 & 12.5 & 0.0 \\
\hline 6. & Limestone & 10.1 & 9.8 & 11.4 \\
\hline 7. & Monocalcium phosphate & 14.1 & 12.7 & 14.2 \\
\hline 8. & L-Lysine & 3.5 & 2.3 & 0.5 \\
\hline 9. & $\mathrm{DL}_{\text {-Methionine }}$ & 2.5 & 2.2 & 2.2 \\
\hline 10. & L-Threonine & 0.5 & 0.4 & 0.0 \\
\hline 11. & Sodium chloride & 1.9 & 2.0 & 2.1 \\
\hline 12. & Sodium bicarbonate & 3.2 & 2.0 & 1.9 \\
\hline 13. & $\begin{array}{l}\text { Vitamin-trace-mineral } \\
\text { premix }^{a}\end{array}$ & 1.0 & 1.0 & 1.0 \\
\hline \multicolumn{5}{|c|}{ Chemical analysis } \\
\hline 14. & DM & 891.2 & 892.1 & 890.6 \\
\hline 15. & $\mathrm{CP}(\mathrm{N} \times 6.25)$ & 245.2 & 231.0 & 204.6 \\
\hline 16. & Crude fat & 57.2 & 75.3 & 91.6 \\
\hline 17. & Crude fiber & 45.1 & 44.6 & 41.4 \\
\hline 18. & Ash & 42.3 & 47.8 & 49.5 \\
\hline \multicolumn{5}{|c|}{ Calculated analysis } \\
\hline 19. & $\mathrm{Ca}$ & 9.3 & 9.1 & 9.0 \\
\hline 20. & $\mathrm{P}$ (total) & 7.0 & 7.0 & 6.7 \\
\hline 21. & Lysine & 14.0 & 13.0 & 11.5 \\
\hline 22. & Methionine + cystine & 11.2 & 10.1 & 9.5 \\
\hline 23. & $\mathrm{ME}, \mathrm{kcal} / \mathrm{kg}$ & 3,060 & 3,180 & 3,200 \\
\hline
\end{tabular}


Table 3: Proximate analysis of Oyster Mushroom (Crude)

Results are mean \pm SE of three replicates of crude mushroom powder samples

\begin{tabular}{|lll|}
\hline No & Character & Mean \pm SE \\
\hline 1 & Moisture $(\mathrm{g} / 100 \mathrm{~g})$ & $3.84 \pm 0.02$ \\
\hline 2 & Ash $(\mathrm{g} / 100 \mathrm{~g})$ & $14.34 \pm 0.04$ \\
\hline 3 & Protein $(\mathrm{g} / 100 \mathrm{~g})$ & $33.24 \pm 0.03$ \\
\hline 4 & Fat $(\mathrm{g} / 100 \mathrm{~g})$ & $1.2 \pm 0.01$ \\
\hline 5 & Carbohydrates $(\mathrm{g} / 100 \mathrm{~g})$ & $48.36 \pm 0.1$ \\
\hline 6 & Energy $(\mathrm{kcal} / 100 \mathrm{~g})$ & $405 \pm 0.18$ \\
\hline
\end{tabular}

Table 4: Qualitative analysis of amino acids in the oyster mushroom sample

\begin{tabular}{|c|c|c|c|c|}
\hline No & Test/Raction & Test Specificity & $\begin{array}{l}\text { Final Color } \\
\text { change }\end{array}$ & Results \\
\hline 1 & Ninhydrin test & $\begin{array}{l}\text { Presence of Amino } \\
\text { Acid }\end{array}$ & Purple & Amino acids present \\
\hline 2 & Xanthoproctic test & Aromatic amino acid & Orange & $\begin{array}{l}\text { Aromatic amino acids } \\
\text { present }\end{array}$ \\
\hline 3 & Million's test & Tyrosine & Brick red & Tyrosine present \\
\hline 4 & Pauly' test & $\begin{array}{l}\text { Tyrosine, Tryptophan, } \\
\text { Histidine }\end{array}$ & Red & Histidine present \\
\hline 5 & Hopkin-Cole test & Tryptophan & Violet ring & Tryptophan present \\
\hline 6 & Sakaguch's test & Arginine & Red & Arginine present \\
\hline 7 & $\begin{array}{l}\text { Sodium Nitroprosside } \\
\text { test }\end{array}$ & $\begin{array}{l}\text { Cysteine and } \\
\text { methionine }\end{array}$ & red & $\begin{array}{l}\text { Cysteine and methionine } \\
\text { present }\end{array}$ \\
\hline 8 & Lead Sulphide test & $\begin{array}{l}\text { Cysteine and } \\
\text { Homocystine }\end{array}$ & $\begin{array}{l}\text { Brown } \\
\text { precipitates }\end{array}$ & Cysteine present \\
\hline 9 & $\begin{array}{l}\text { Folin's McCarthy } \\
\text { Sullivan test }\end{array}$ & $\begin{array}{l}\text { Proline and } \\
\text { Hydroxyproline }\end{array}$ & Red & Proline present \\
\hline
\end{tabular}

Table 5: quantification of different amino acids ( $\mathrm{mg} / \mathrm{g} \pm \mathrm{SEM}$ ) evaluated by different extraction methods in Oyster Mushroom. 
Values are mean \pm SD of three independent determination.

Different letters in superscript represent significant $(p<0.05)$ difference among different samples.

\begin{tabular}{|llll|}
\hline \multirow{2}{*}{ Sr No } & Compounds Concentrations $(\mathrm{mg} / \mathrm{g})$ & \multicolumn{2}{l}{ Oyster Mushroom Extracts } \\
\cline { 3 - 4 } & & Ethanolic & Aqueous \\
\hline 1 & Phenylalanine & $1.05 \pm 0.05$ & $4.28 \pm 0.13$ \\
\hline 2 & Taurine & $8.51 \pm 0.43$ & $4.36 \pm 0.14$ \\
\hline 3 & Threonine & $8.05 \pm 0.40$ & $72.90 \pm 2.19$ \\
\hline 4 & Asparagine & $0.48 \pm 0.02$ & $91.40 \pm 2.74$ \\
\hline 5 & Aspartic acid & -- & - \\
\hline 6 & Citric acid & -- & $9.78 \pm 0.29$ \\
\hline 7 & Cysteine & $3.17 \pm 0.16$ & $110.10 \pm 3.30$ \\
\hline 8 & methionine & $5.95 \pm 0.30$ & $1.12 \pm 0.03$ \\
\hline 9 & Isoleucine & -- & - \\
\hline 10 & Leucine & -- & $1.10 \pm 0.03$ \\
\hline 11 & B-ala & $31.56 \pm 1.58$ & $36.87 \pm 1.11$ \\
\hline 12 & Pea & $0.03 \pm 0.00$ & $0.29 \pm 0.01$ \\
\hline 13 & Serine & $5.05 \pm 0.25$ & - \\
\hline 14 & Tyrosine & $7.27 \pm 0.36$ & - \\
\hline 15 & Baiba & $15.99 \pm 0.80$ & - \\
\hline 16 & Glycine & -- & $210.53 \pm 6.32$ \\
\hline
\end{tabular}

\section{Figures}



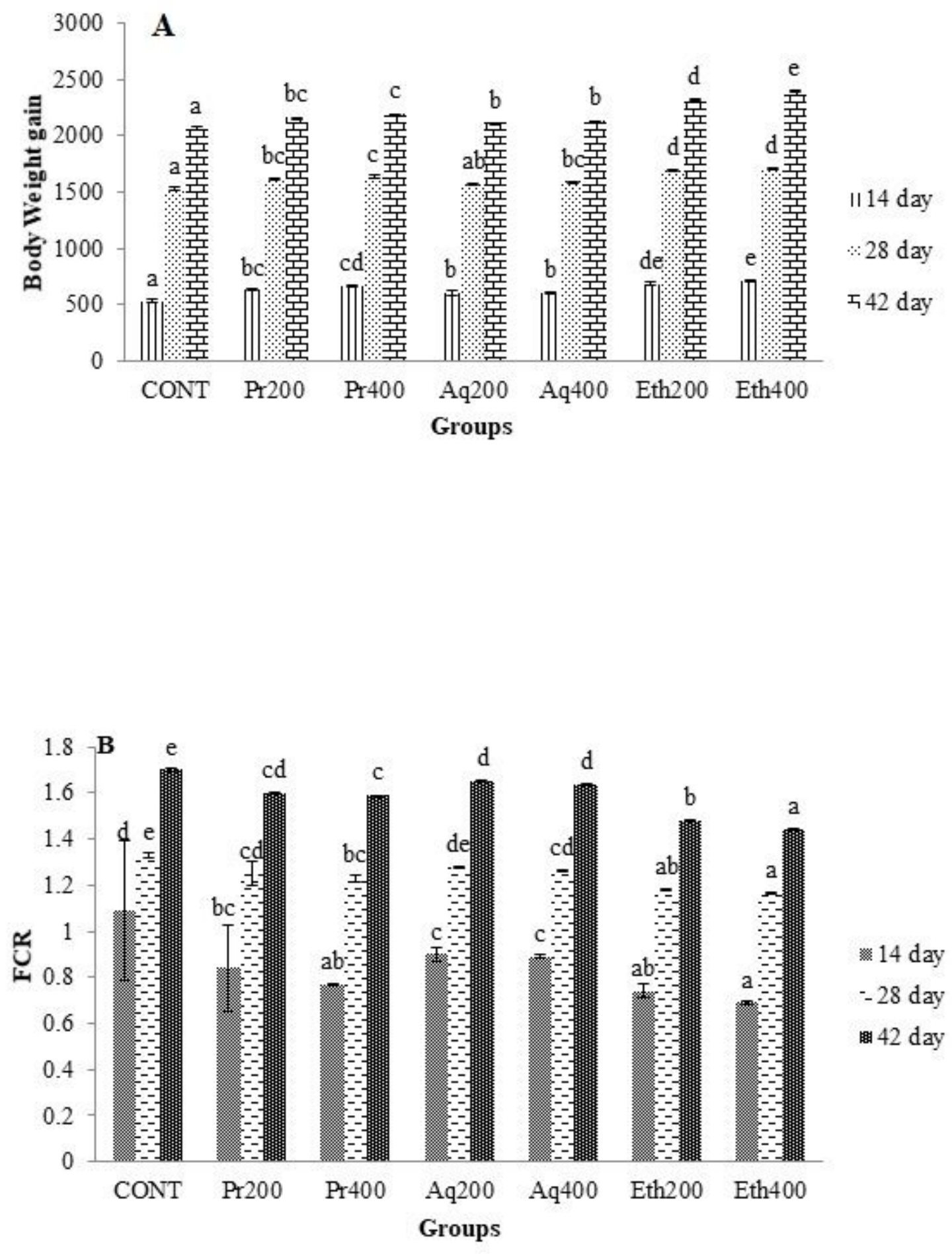

Figure 1

A: Body weight (BW) in all groups of broiler birds At 14, 28 \& 42 day B: Feed Conversion Ratio $(F C R)$ in all groups of broiler birds a-c Means within a column with no common superscript differ significantly $(\mathrm{P}<$ $0.05)$. 
A

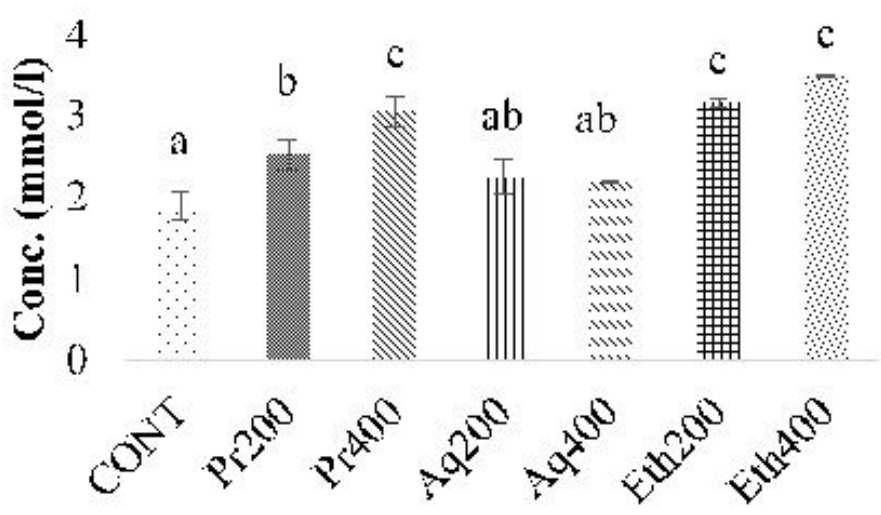

Groups
B TOS $(\mathrm{mmol} / \mathrm{l})$



Groups
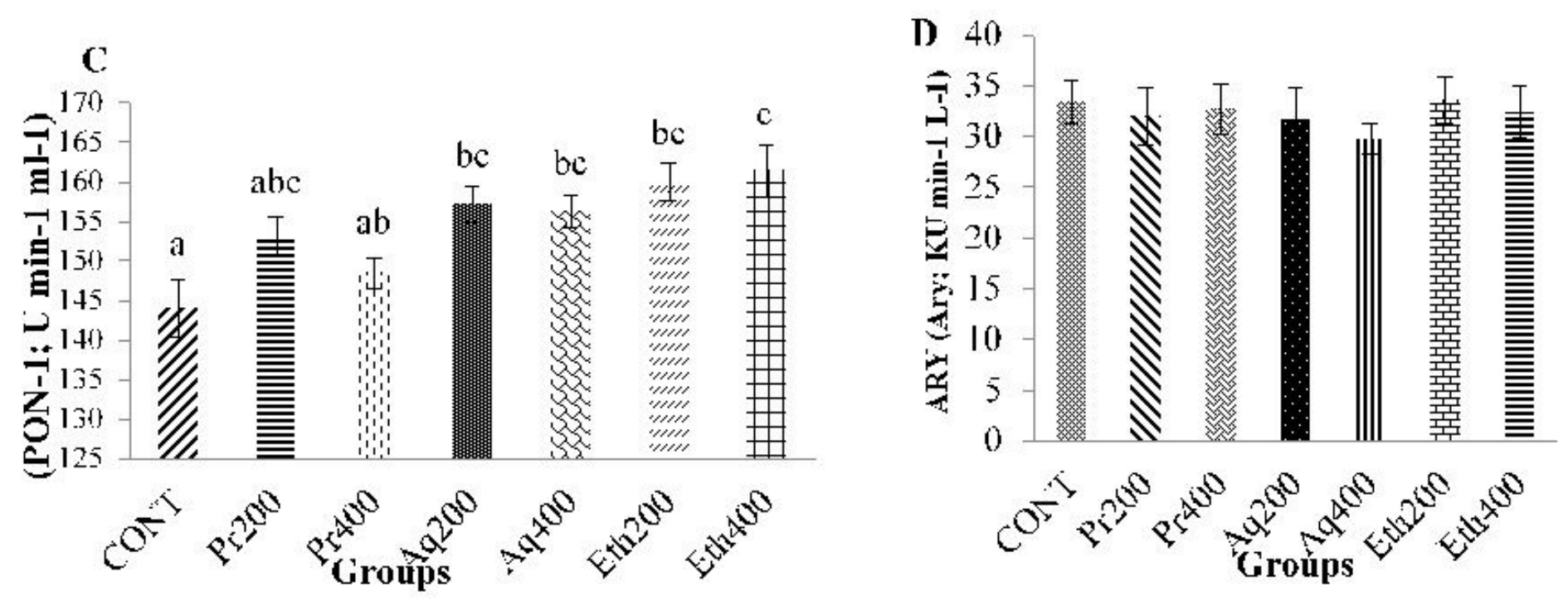

Figure 2

Oxidative stress in all the groups of broiler birds. A: TAC (Total antioxidant capacity; mmol/l) B: TOS ( Total oxidant status; mmol/I) C: PON: (Paraoxonase activity; PON-1; U min-1 ml-1) D: ARY: (Arylesterase Activity; KU min-1 L-1) . a-c Means within a column with no common superscript differ significantly $(\mathrm{P}<$ 0.05). 

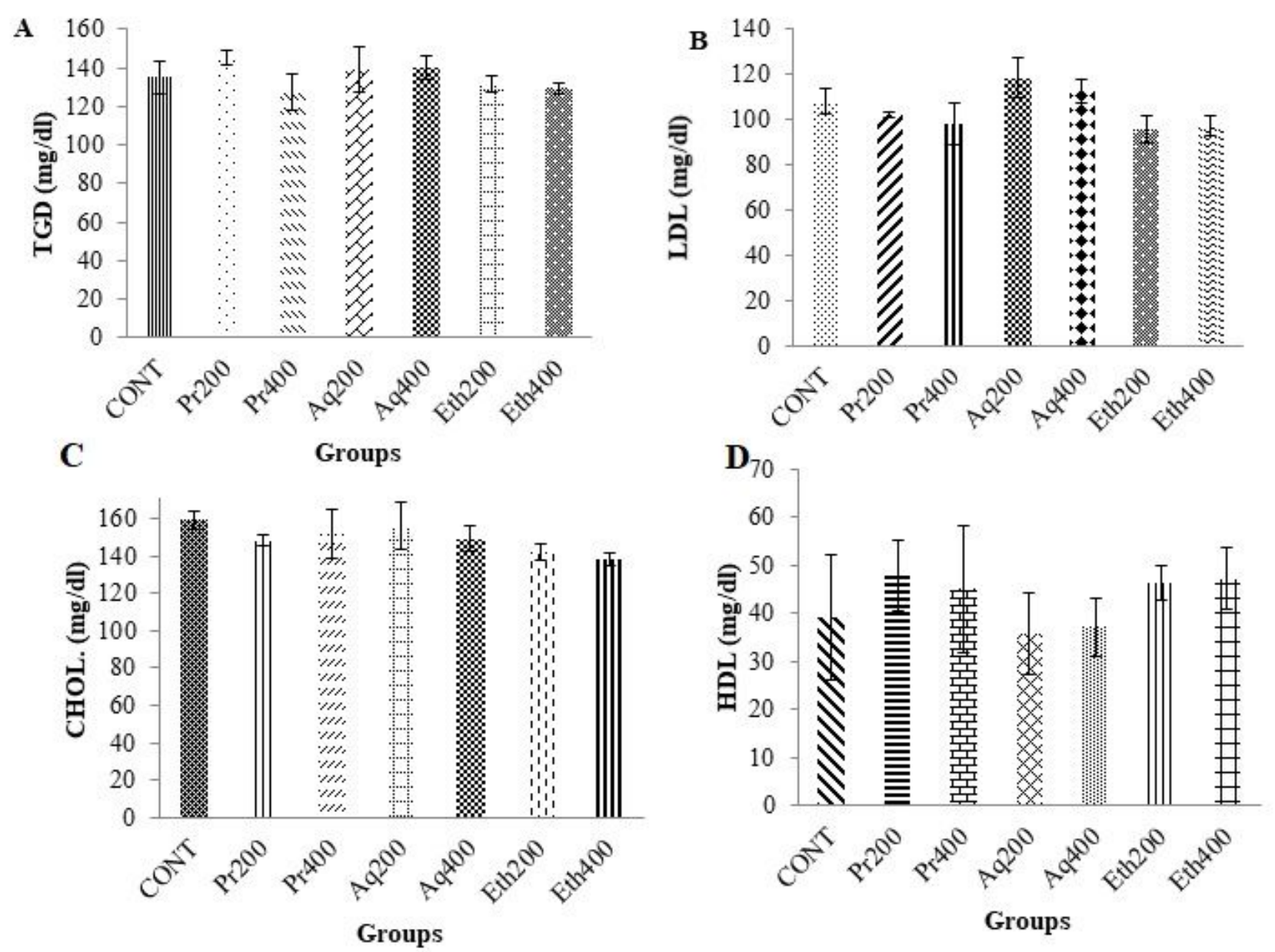

Figure 3

Lipid Profile in all groups of broiler birds: A: TGD (Triglyceride levels; mg/dl) B: LDL (Low Density Lipoproteins; mg/dl) C: CHOL (Total Cholesterol Level; mg/dl) D: HDL (High density Lipoproteins Level; $\mathrm{mg} / \mathrm{dl})$ a-c Means within a column with no common superscript differ significantly $(P<0.05)$.

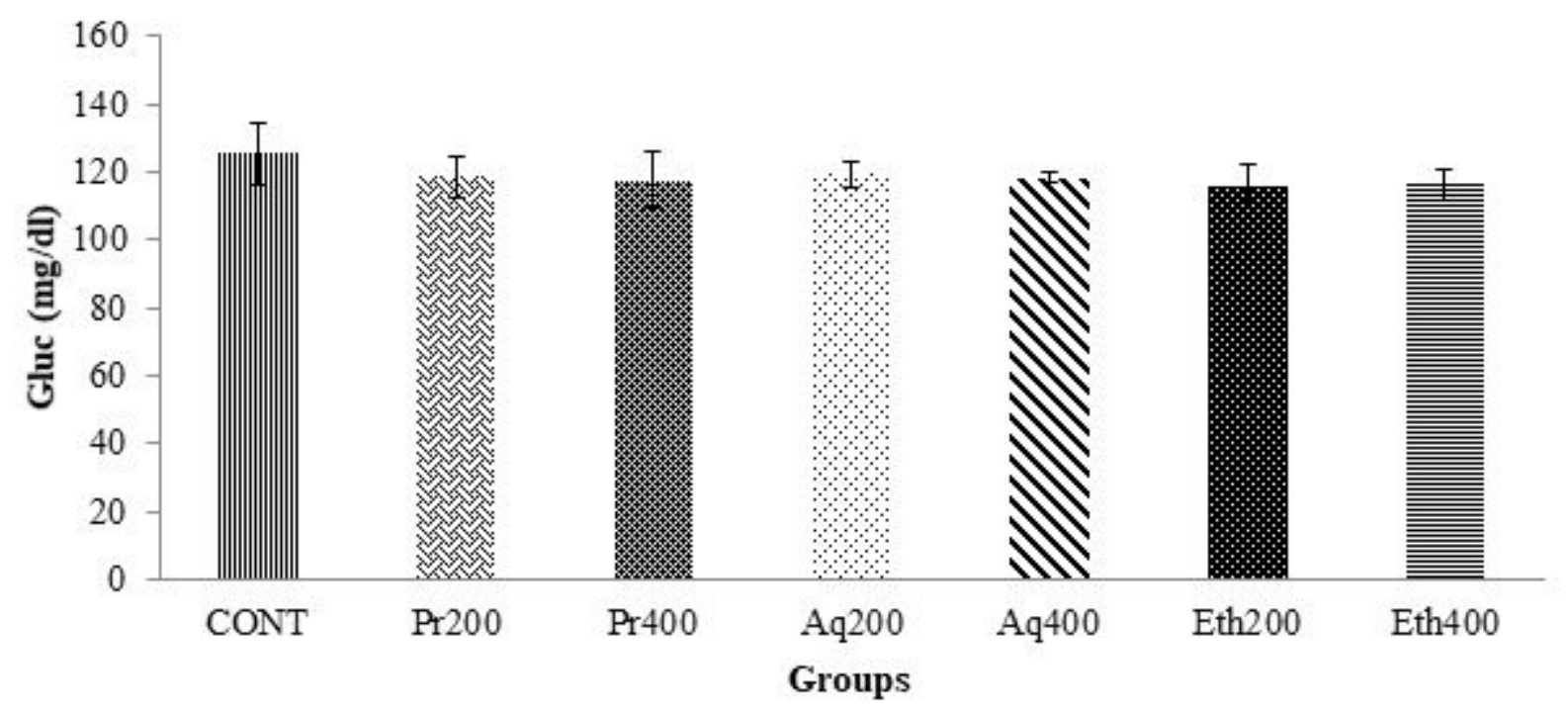

Figure 4 
Serum glucose level in all groups of broiler birds

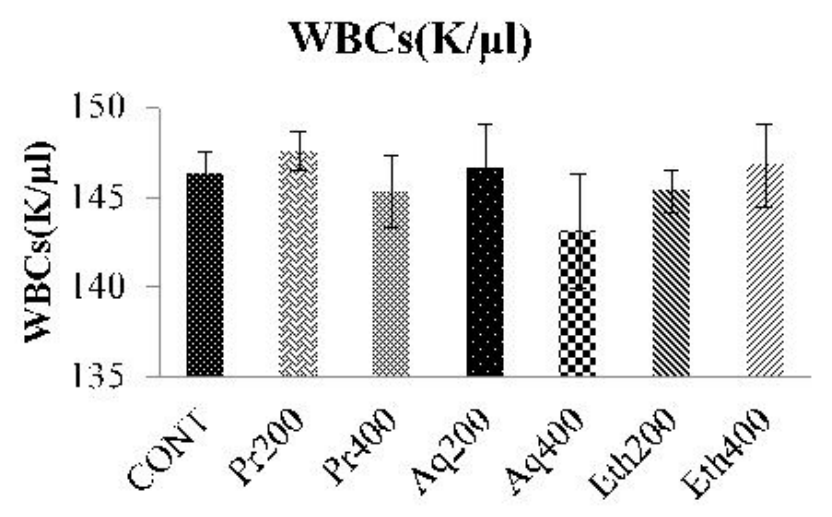

Groups

C

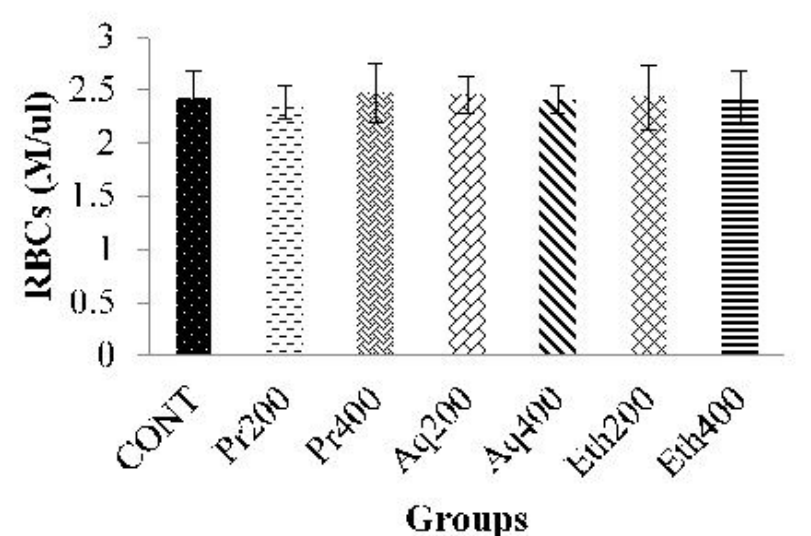

E

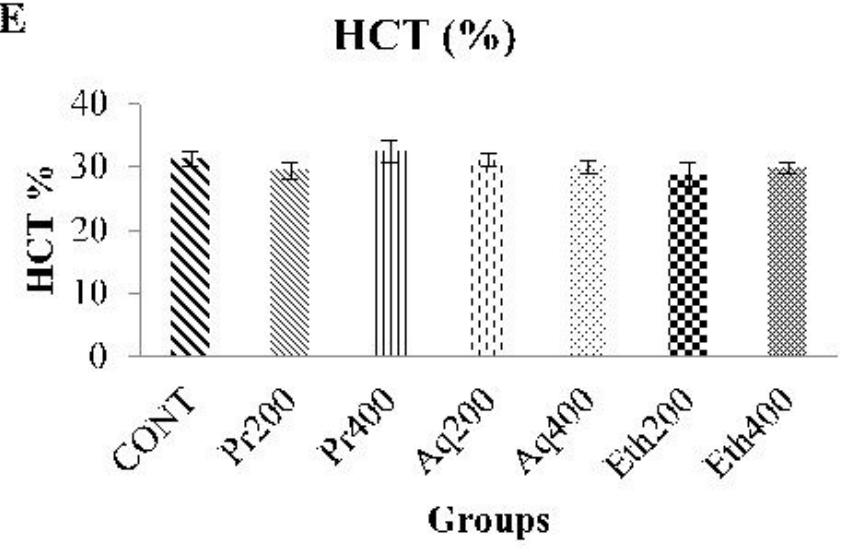

B $\quad$ LYM $(\%)$

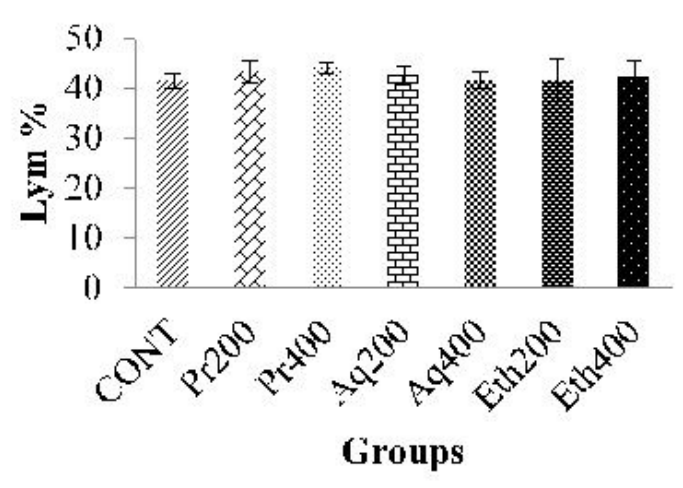

$\mathrm{D}$



\section{Figure 5}

Hematology of all groups of broiler birds A: WBCs; White blood cells, B: LYM; Lymphocytes, C: RBCs; Red Blood Cells, D: HBG; Hemoglobin, E: HCT; Hematocrit 


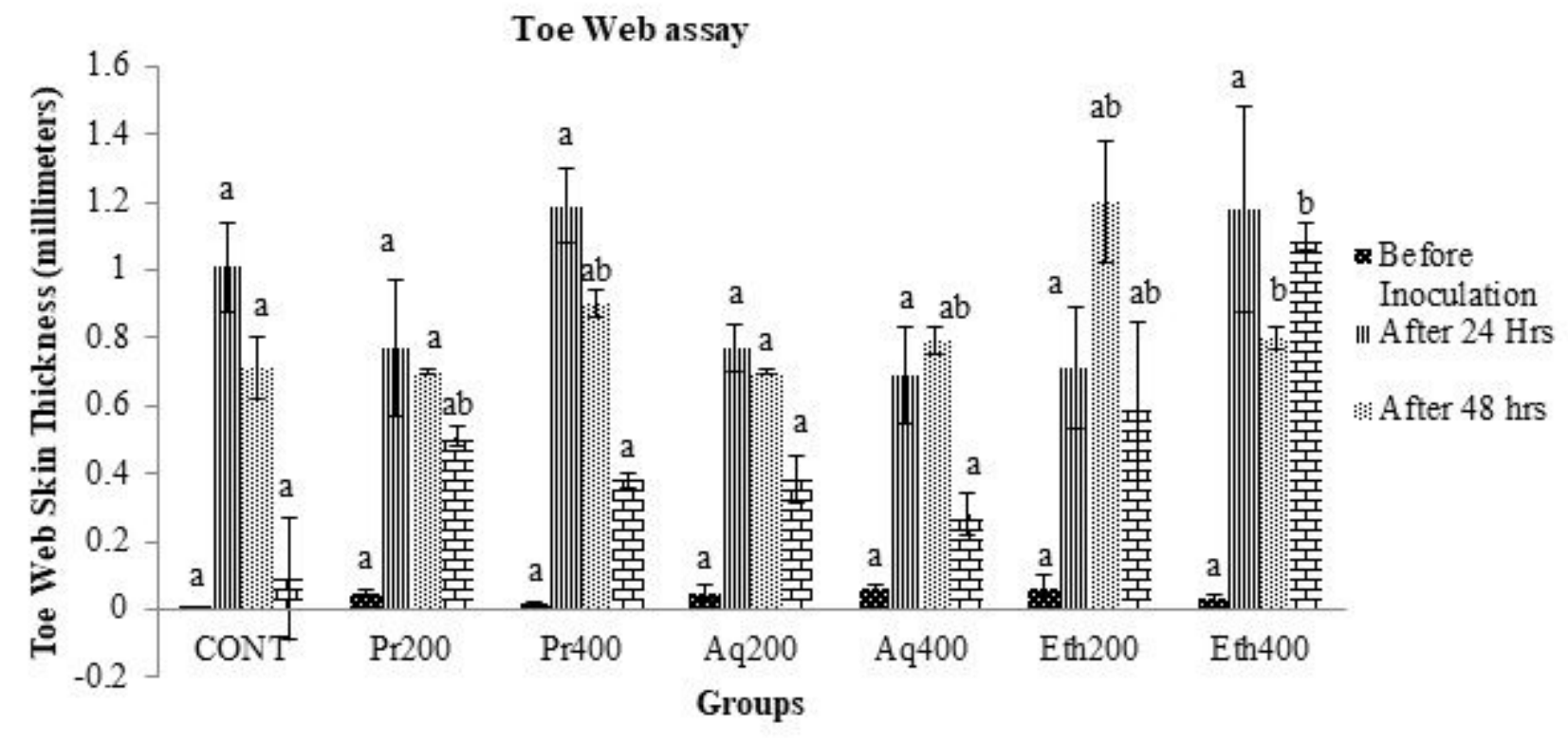

Figure 6

Toe Web Skin Thickness (millimeters) in all groups of broiler birds. a-c Means within a column with no common superscript differ significantly $(P<0.05)$.

\section{Haemagglutination Assay}

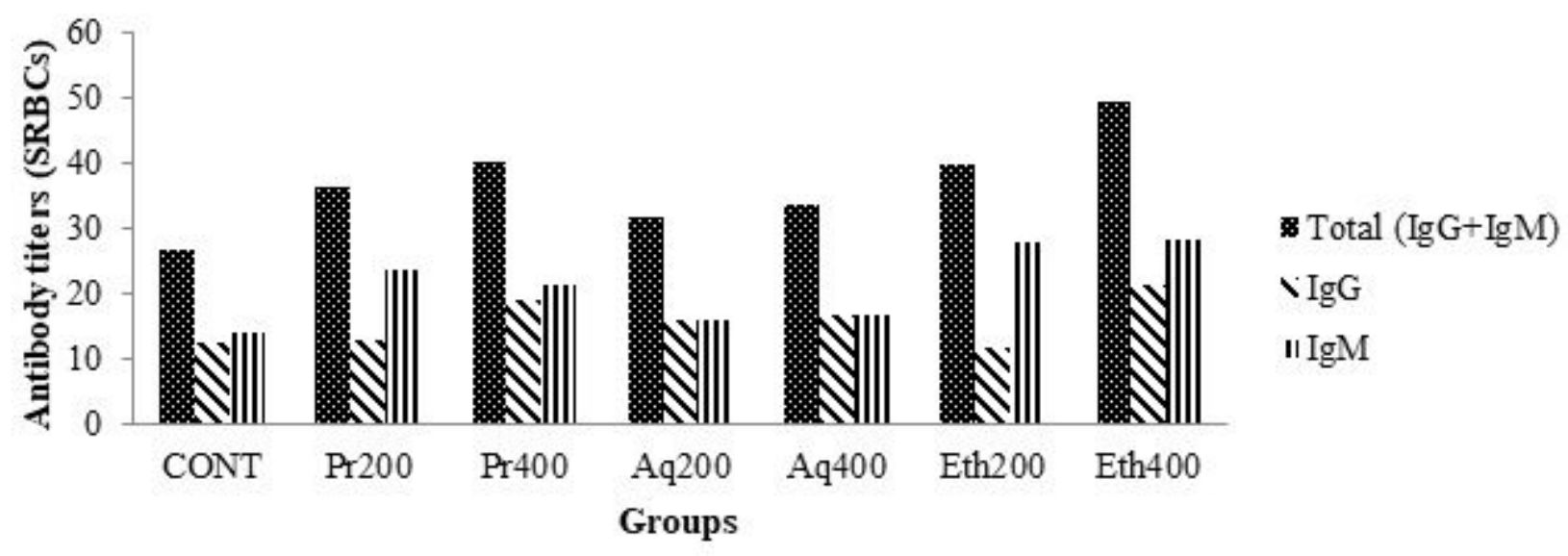

Figure 7

Haemagglutination Assay in all groups of broiler birds Total anti-SRBC antibody, IgG, IgM titres and total $(\lg \mathrm{G}+\lg \mathrm{M}))$

\section{Supplementary Files}

This is a list of supplementary files associated with this preprint. Click to download.

- AuthorChecklistFull.pdf 